\title{
PENGGUNAAN TERAPI MUSIK UNTUK MENURUNKAN KELELAHAN AKIBAT PENGOBATAN PADA PASIEN KANKER SERVIKS: STUDI KASUS
}

\author{
Fitriana Ega Rachmawati ${ }^{1}$, Monty P. Satiadarma ${ }^{2}$, Arlends Chris ${ }^{3}$ \\ ${ }^{1}$ Psikologi Profesi, Universitas Tarumanagara Jakarta \\ Email: fitriana.717181005@stu.untar.ac.id \\ ${ }^{2}$ Fakultas Psikologi, Universitas Tarumanagara Jakarta \\ Email: montys@fpsi.untar.ac.id \\ ${ }^{3}$ Fakultas Kedokteran, Universitas Tarumanagara Jakarta \\ Email: arlendsc@fk.untar.ac.id
}

Masuk : 16-11-2020, revisi: 23-03-2021y, diterima untuk diterbitkan : 26-03-2021

\begin{abstract}
Treatment of cervical cancer patients can cause casualties in these patients. The fatigue felt by the individual can affect the quality of life of the patient. Music therapy is an alternative therapy that cervical cancer patients can give to help reduce the feelings felt by the patient. The music therapy that is given does not aim to cure the patient, but as a tool to treat the patient's feelings as a result. Music therapy is therapeutic, it can provide emotional and spiritual support. So that it can reduce fatigue due to treatment. The reduction in fatigue and fatigue by the patient can help him in the process of further healing. This study is a quasi-experimental study with a pretest-post test model given to cervical cancer patients. The music used was a type of Baroque, namely Pachelbel and J. S. Bach. The choice of this type of music is because it can provide a relaxing effect on the patient. This study also used a measuring tool in the form of Cancer Therapy Functional Assessment: Fatigue (FACIT-F) to see the level of improvement in patients. Other tools used are GSR2 and a heart rate measuring device, to see a graph of the patient's perceived relationship. This study has the results that Baroque type music therapy can help eliminate cervical cancer patients who are undergoing treatment, although not in the long term. The music that the patient listens can help the patient feel relaxed and calm, so that after listening to music the patient can rest and forget the pain even if only temporarily.
\end{abstract}

Keywords: Music therapy, baroque music, fatigue, cervical cancer

\begin{abstract}
ABSTRAK
Pengobatan yang dijalani pasien kanker serviks dapat menimbulkan kelelahan pada pasien tersebut. Kelelahan yang dirasakan oleh individu dapat memengaruhi kualitas hidup dari pasien. Terapi musik adalah salah satu terapi alternatif yang dapat diberikan kepada pasien kanker serviks untuk membantu menurunkan kelelahan yang dirasakan oleh pasien. Terapi musik yang diberikan tidak bertujuan untuk menyembuhkan pasien, tetapi sebagai alat bantu untuk menurunkan kelelahan yang dirasakan oleh pasien akibat pengobatan yang dijalaninya. Terapi musik yang bersifat terapeutik, dapat memberikan dukungan secara emosional dan spiritual. Sehingga dapat mengurangkan rasa lelah akibat pengobatan. Menurunnya rasa lelah yang dialami oleh pasien tersebut dapat membantunya dalam proses penyembuhan yang lebih lanjut. Penelitian ini merupakan penelitian quasi-experiment dengan model pretest-post test yang diberikan kepada pasien kanker serviks. Musik yang digunakan adalah jenis Baroque yaitu Pachelbel dan J. S. Bach. Pemilihan jenis musik ini karena dapat memberikan efek relaksasi pada pasien. Penelitian ini juga menggunakan alat ukur berupa Functional Assessment of Cancer Therapy: Fatigue (FACIT-F) untuk melihat tingkat kelelahan pada pasien. Alat bantu lainnya yang digunakan adalah GSR2 dan alat ukur detak jantung, untuk melihat grafik relaksasi yang dirasakan oleh pasien. Penelitian ini memiliki hasil bahwa terapi musik jenis Baroque dapat membantu menghilangkan kelelahan pada pasien kanker serviks yang sedang menjalani pengobatan walaupun bukan dalam jangka panjang. Musik yang didengarkan oleh pasien dapat membantu pasien merasa rileks dan tenang, sehingga setelah selesai mendengarkan musik pasien dapat beristirahat dan melupakan rasa sakitnya walaupun hanya sementara.
\end{abstract}

Kata Kunci: Terapi musik, musik baroque, kelelahan, kanker serviks 


\section{PENDAHULUAN}

\section{Latar Belakang}

Kanker serviks adalah salah satu jenis kanker yang paling banyak mengancam kehidupan para wanita di seluruh dunia. Setiap tahun, adanya peningkatan jumlah pasien kanker serviks di dunia maupun di dunia. Menurut Bray et al. (2018), kanker serviks berada di urutan ke-3 kanker yang paling banyak didiagnosis oleh wanita di seluruh dunia. Pada tahun 2018, terdapat 569.847 kasus kanker serviks baru dan 311.365 kasus kematian di seluruh dunia. Pada tahun 2018, terdapat 32.469 kasus wanita didiagnosis kanker serviks dengan 18.279 kasus kematian di Indonesia (WHO, 2018).

Banyak faktor seseorang dapat diagnosis kanker, diantaranya adalah faktor keturunan dan genetik. Penyebab utama pada kanker serviks adalah infeksi human papillomavirus (HPV). Selain itu adanya gaya hidup yang kurang sehat, seperti asupan makanan yang tidak seimbang, kurangnya berolahraga, minum-minuman beralkohol, merokok, dan dampak lain dari lingkungan hidup. Faktor imunitas dari individu juga dapat menjadi faktor tambahan seseorang dapat didiagnosis kanker (Bruni et al., 2018).

Individu yang didiagnosis kanker, kerap harus menjalani proses terapi yang dapat berlangsung lama dan membutuhkan biaya tinggi. Terdapat banyak macam pengobatan yang dapat diterapkan pada pasien kanker, diantaranya adalah operasi, radioterapi, kemoterapi, imunoterapi, dan terapi gen (National Cancer Institute, 2017). Pengobatan yang diberikan oleh dokter kepada pasien sangat tergantung pada jenis kanker dan stadium dari pasien tersebut. Pengobatan yang diberikan juga akan berbeda pada setiap pasien, walaupun jenis kanker yang diidap sama. Usia dari pasien juga dapat memengaruhi pengobatan yang akan diberikan pada pasien tersebut.

Pengobatan yang dijalani oleh pasien dapat menimbulkan kelelahan. Rasa lelah yang berlangsung lama menyebabkan pasien mengalami kehilangan semangat dan tenaga untuk melanjutkan pengobatan. Kehilangan semangat dan tenaga tersebut dapat membuat pasien tidak melanjutkan pengobatan yang harus ia jalani (Dimeo et al., 1999). Kelelahan yang dirasakan oleh pasien akibat pengobatan dapat mencakup aspek fisik dan psikis. Secara fisik, pasien merasa lebih mudah lelah, lemah, dan kurang memiliki energi dalam melakukan kegiatan sehari-hari. Secara psikis, pasien dapat merasa tertekan karena pengobatan yang berlangsung lama dan biaya yang besar. Kelelahan tersebut dapat memengaruhi self-esteem, aktivitas sosial, dan kualitas hidup dari pasien tersebut. 70-100\% pasien kanker merasakan kelelahan selama pengobatan berlangsung (Alcântara-Silva, et. al., 2018).

Beberapa indikasi kelelahan yang dialami pasien dalam proses pengobatan adalah kesulitan untuk beristirahat. Kurangnya istirahat dapat mengganggu proses pemulihan diri sehingga memengaruhi energi dan aktivitas. Efek samping yang dirasakan oleh pasien akibat pengobatan seperti mual, pusing, dan sakit secara fisik dapat memengaruhi kesulitan dalam beristirahat.

Terdapat beberapa macam kegiatan alternatif yang dapat diberikan untuk memulihkan rasa lelah yang dirasakan oleh pasien, salah satunya adalah aktivitas musik. Musik yang bersifat terapeutik, menjadi salah satu terapi yang dapat diberikan kepada pasien. Terapi ini berguna untuk mengurangi rasa lelah dari pengobatan yang dijalani, kecemasan, dan depresi yang mungkin dialami oleh pasien kanker. Terapi musik juga dapat membantu individu untuk lebih mudah merasa rileks dan nyaman. Musik juga dapat memberikan efek kepada pasien untuk melupakan rasa sakit dan kelelahan yang diakibatkan oleh pengobatan, sehingga pasien dapat mengalihkan atensi dan pikiran dari penyakit diderita (Bulfone et al., 2009). Musik memiliki unsur-unsur yang 
dapat memberikan efek terapi, sehingga dapat meningkatkan kesehatan mental dan fisik dari pasien. Musik tersebut juga dapat memberikan dukungan emosional dan spiritual pada pasien, sehingga membantu dalam mengurangi stres dan kecemasan. Musik yang memberikan efek relaksasi memberikan emosi positif yang dapat meningkatkan aktivitas sistem saraf pasien (Chuang et al., 2011).

Terdapat beberapa macam musik yang dapat digunakan sebagai media terapi, salah satunya adalah musik Baroque. Musik Baroque merupakan salah satu jenis musik yang sering digunakan sebagai sarana terapeutik. Musik Baroque sendiri memberikan efek yang menenangkan sehingga dapat membantu seseorang untuk lebih merasa tenang dan relaks. Musik Baroque yang memiliki tempo largo (60-80 bpm) dapat memberikan efek menenangkan dan relaksasi pada individu yang mendengarkannya (Encyclopedia Britannica, 2019). Musik Baroque memiliki beberapa karakteristik yang berbeda dari jenis musik lainnya, seperti kontras, keras dan lembut, perbedaan instrumen, dan timbre pada komposisi musik. Adanya fitur musik yang stabil seperti bass, membantu individu untuk lebih mudah dan fokus pada musik yang ia dengarkan. Pengulangan bagian-bagian identik pada interval yang sama dalam musik Baroque, menjadi salah satu karakteristik yang mempermudah individu dalam memfokuskan diri pada musik (Wigram et al., 2002)

\section{Rumusan Masalah}

Berdasarkan identifikasi masalah yang telah dilakukan, rumusan masalah dalam penelitian ini adalah untuk melihat apakah musik terapi dapat digunakan untuk membantu menurunkan kelelahan pada pasien kanker serviks akibat pengobatan yang dijalaninya?

\section{METODE PENELITIAN \\ Partisipan penelitian}

Partisipan pada penelitian ini adalah seorang wanita berinisial $\mathrm{N}$ berusia 36 tahun yang sudah didiagnosis kanker serviks stadium 2A. Partisipan merupakan pasien dari salah satu rumah singgah Jakarta yang menampung pasien kanker yang menjalani pengobatan.

\section{Instrumen penelitian}

Instrumen yang digunakan dalam penelitian ini adalah Functional Assessment of Cancer Therapy: Fatigue (FACIT-F) versi 4. Penggunaan alat ukur ini untuk melihat gambaran kelelahan yang sering dialami oleh pasien kanker dan memang dikhususkan kepada pasien kanker. Alat ukur ini memiliki validitas internal yang tinggi (Cronbach's alpha $=0.96$ ) dan test-retest reliabilitas (ICC $=0.95$ ). Alat ukur ini terdiri dari 40 buat pernyataan, dan subjek diminta untuk menilai dengan cara melingkari 0 (tidak sama sekali) hingga 4 (selalu). Semakin tinggi skor (160) FACIT-F secara keseluruhan, maka semakin baik pula quality of life dari seseorang. Kelelahan dapat diukur dari Fatigue Subscale (FS) yang ada di FACIT-F. Semakin rendah skor (0) pada FS maka semakin buruk kondisi kelelahan yang dialami oleh seseorang, begitu pula sebaliknya semakin tinggi (52) skor pada FS maka semakin baik kondisi dari pasien. Jika pasien mendapatkan skor <30 maka pasien tersebut dapat dikatakan memiliki tingkat kelelahan yang cukup parah (Tennant, 2019).

\section{Teknik pengolahan data}

Penelitian ini merupakan penelitian quasi-experiment dengan model pretest-post test yang diberikan kepada pasien kanker serviks menggunakan kuesioner FACIT-F. 


\section{HASIL DAN PEMBAHASAN}

$\mathrm{N}$ adalah pasien kanker serviks stadium $2 \mathrm{~A}$ yang sudah didiagnosis selama 2 tahun. $\mathrm{N}$ sudah menjalani pengobatan kanker serviks selama 2 tahun dengan metode sinar dan operasi. Sebelum diberikannya intervensi musik terapi, $\mathrm{N}$ memiliki nilai kelelahan yang cukup tinggi pada skor FACIT-F. Secara keseluruhan N memiliki nilai 122 dan skor Fatigue Scale 34, ia menggambarkan rasa lelah yang dirasakan seperti letih, tubuh yang terasa lemah, dan kesulitan dalam memulai aktivitas. $\mathrm{N}$ mengatakan akibat pengobatan yang ia jalani membuatnya membutuhkan istirahat yang lebih banyak dibandingkan sebelumnya, tetapi karena kelelahan tersebut juga membuatnya merasa kesulitan beristirahat dengan baik.

\section{Tabel 1}

Dampak Terhadap Kelelahan Selama Proses Terapi

\begin{tabular}{cccccc}
\hline & \multicolumn{5}{c}{ A } \\
Dampak Terapi & 1 & 2 & 3 & 4 & 5 \\
\cline { 2 - 6 } Perbaikan Pola Tidur & $\sqrt{ }$ & $\sqrt{ }$ & $\sqrt{ }$ & $\sqrt{ }$ & $\sqrt{ }$ \\
Rasa Sakit Berkurang & - & - & $\sqrt{ }$ & $\sqrt{ }$ & $\sqrt{ }$ \\
Rileks/Nyaman & $\sqrt{ }$ & $\sqrt{ }$ & $\sqrt{ }$ & $\sqrt{ }$ & $\sqrt{ }$ \\
\hline
\end{tabular}

Selama pemberian intervensi musik terapi, $\mathrm{N}$ mengalami beberapa perubahan. Pada awal pertemuan intervensi, $\mathrm{N}$ masih mengalami kesulitan untuk mengatur pernafasannya dan fokus kepada musik yang sedang ia dengarkan. Sehingga ia cenderung mengalami relaksasi secara bertahap. Detak jantung N dalam rentang yang stabil. Setelah pertemuan pertama, N sudah mulai mudah mengatur pernafasan dan memfokuskan diri pada musik yang ia dengarkan. Setiap pertemuan intervensi selanjutnya, $\mathrm{N}$ semakin merasa mudah untuk mengatur pernafasan dan memfokuskan diri dengan musik yang didengarkan. Sehingga relaksasi yang ia rasakan semakin cepat dan berlangsung lebih lama.

Musik yang didengarkan $\mathrm{N}$, selain membantunya merasa lebih relaks, juga membantunya membayangkan tempat yang dapat memberikan kenyamanan. Oleh karena itu, $\mathrm{N}$ dapat melupakan sejenak rasa sakit yang dirasakan akibat pengobatan yang sedang dijalani. Setiap selesai menjalani musik terapi, $\mathrm{N}$ merasa bahwa tubuhnya lebih ringan dan tidak merasakan nyeri. $\mathrm{N}$ juga mengatakan bahwa setiap setelah melaksanakan musik terapi, ia merasa lebih mudah untuk beristirahat dan dapat tidur dengan cepat dan dalam waktu yang lebih lama. Jika sebelumnya $\mathrm{N}$ mengalami kesulitan untuk tidur dan mengistirahatkan diri, setelah terapi ia merasa lebih mudah untuk tidur dan beristirahat sehingga dapat memulihkan rasa lelahnya.

Dapat dilihat dari Tabel 1, bahwa setiap lima kali pertemuan terapi musik, $\mathrm{N}$ mengalami perbaikan pola tidur dan merasa relaks di setiap pertemuannya. Sedangkan pada pertemuan ke 3-5, N merasa bahwa rasa sakit yang biasanya ia rasakan seperti berkurang dan menghilang selama mendengarkan musik. Walaupun $\mathrm{N}$ mengatakan bahwa merasakan adanya perubahan, biasanya perubahan tersebut tidak berlangsung lama. $\mathrm{N}$ mengatakan bahwa keesokan harinya ia masih sering merasa sakit, tetapi karena pola tidur sehari sebelumnya lebih baik, saat pagi hari $\mathrm{N}$ merasa lebih segar dan memiliki tenaga yang lebih besar jika dibandingkan sebelumnya. 
Tabel 2

Gambaran Pre-Test dan Post-Test FACIT-F

\begin{tabular}{ccc}
\hline FACIT-F & \multicolumn{2}{c}{$\mathrm{N}$} \\
\cline { 2 - 3 } & Pre-test & Post-test \\
\hline Keseluruhan & 122 & 151 \\
Fatigue Subscale & 34 & 49 \\
\hline
\end{tabular}

Setelah selesai melakukan rangkaian intervensi musik terapi sebanyak lima kali, $\mathrm{N}$ merasakan lebih mudah dalam beristirahat. $\mathrm{N}$ juga merasa bahwa ia lebih mudah untuk memfokuskan pada keadaan dirinya bukan hanya memfokuskan pada rasa sakit yang dirasakan. $\mathrm{N}$ juga mengatakan bahwa lebih mudah untuk menstabilkan emosinya dan lebih mudah merasa tenang dalam menghadapi kondisi dan situasi yang sedang dialaminya. Saat pemberian post test, hasil FACIT-F N mengalami perubahan yaitu secara keseluruhan 151 dan Fatigue Scale 49. Hal tersebut menunjukkan bahwa adanya peningkatan yang cukup tinggi. Peningkatan tersebut menunjukkan bahwa $\mathrm{N}$ merasakan lebih mudah beristirahat, sehingga kelelahan yang ia rasakan tidak seintens sebelum diberikannya intervensi musik terapi. Selain itu, skala kelelahan yang dirasakan oleh N juga mengalami peningkatan, dari sebelumnya 34 menjadi 49. Hal ini menunjukkan bahwa $\mathrm{N}$ mengalami penurunan kelelahan dan efek terapi musik yang positif. Rasa lelah yang berkurang tersebut juga dapat memengaruhi kualitas hidup dari $\mathrm{N}$ menjadi lebih baik dan positif.

\section{KESIMPULAN DAN SARAN}

Pengobatan yang dijalani oleh pasien kanker serviks dapat menimbulkan kelelahan. 70-100\% pasien kanker akan mengalami kelelahan akibat pengobatan yang dijalaninya. Kelelahan yang dirasakan tersebut dapat mengganggu pasien dalam hal emosi dan kesehatan secara fisik. Keadaan memburuk dan kelelahan yang terlalu parah dapat memengaruhi proses penyembuhan dari pasien. Terdapat berbagai macam jenis media yang dapat membantu proses penyembuhan dan menghilangkan rasa lelah pada pasien kanker. Salah satu media terapeutik yang dapat diberikan kepada pasien kanker adalah musik terapi. Musik terapi dapat diberikan kepada pasien kanker yang mengalami kelelahan untuk membantu menghilangkan rasa lelah dan istirahat. Sehingga pasien dapat beristirahat dan memulihkan diri walaupun efek dari musik terapi sendiri tidak diperuntukkan untuk jangka panjang dan juga menghilangkan rasa lelah. Musik terapi lebih diperuntukkan sebagai media yang dapat membantu pasien untuk relaksasi sehingga lebih mudah beristirahat. Pada kasus $\mathrm{N}$ sendiri, musik terapi yang diberikan membantu $\mathrm{N}$ untuk lebih mudah beristirahat seperti tidur setelah proses musik terapi itu sendiri. Terapi ini juga memberikan efek untuk melupakan keadaan dan rasa sakit yang dirasakan pasien, dengan cara memfokuskan diri pada pernafasan serta juga musik yang ia dengar.

Saran untuk penelitian selanjutnya yang ingin menggunakan musik terapi, dapat menggunakan jenis musik lainnya selain Baroque. Selain itu, dapat diterapkan pada jenis penyakit lainnya selain kanker serviks. Penelitian ini diharapkan menjadi salah satu tambahan terapi yang dapat diberikan dan diterapkan kepada pasien kanker yang mengalami kelelahan. Penelitian ini juga diharapkan dapat menjadi salah satu pengenalan lainnya mengenai musik yang memberikan sifat terapeutik kepada pasien kanker, sehingga membantu dalam proses penyembuhan dari pasien kanker.

\section{Ucapan Terima Kasih}

Peneliti mengucapkan terima kasih kepada pihak yayasan rumah singgah yang telah mengizinkan peneliti dalam melakukan penelitian. Peneliti juga tidak lupa mengucapkan terima kasih kepada partisipan yang telah bersedia meluangkan waktunya dan berpartisipasi dalam penelitian ini. 


\section{REFERENSI}

Alcântara-Silva, T. R., de Freitas-Junior, R., Freitas, N. M. A., de Paula Junior, W., da Silva, D. J., Machado, G. D. P., Ribeiro, M. K. A., Carneiro, J. P., \& Soares, L. R. (2018). Music therapy reduces radiotherapy-induced fatigue in patients with breast or gynecological cancer: A randomized trial. Integrative Cancer Therapies, 17(3), 628-635. https://www.doi.org/10.1177/1534735418757349

Bray, F., Ferlay, J., Soerjomataram, I., Siegel, R. L., Torre, L. A., \& Jemal, A. (2018). Global cancer statistics 2018: GLOBOCAN estimates of incidence and mortality worldwide for 36 cancers in 185 countries. CA: A Cancer Journal for Clinicians. https://www.doi.org/10.3322/caac. 21492

Bruni, L., Albero, G., Serrano, B., Mena, M., Gómez, D., Muñoz, J., Bosch, F. X., \& de Sanjosé, S. (2018). Human papillomavirus and related diseases in Indonesia. ICO/IARC Information Centre On HPV and Cancer (HPV Information Centre). www.hpvcentre.net

Bulfone, T., Quattrin, R., Zanotti, R., Regattin, L., \& Brusaferro, S. (2009). Effectiveness of music therapy for anxiety reduction in women with breast cancer in chemotherapy treatment. $\begin{array}{llll}\text { Holistic Nursing } & \text { Practice, } & \text { 23(4), }\end{array}$ https://www.doi.org/10.1097/hnp.0b013e3181aeceee

Chuang, C.-Y., Han, W.-R., Li, P.-C., Song, M.-Y., \& Young, S. T. (2011). Effect of long-term music therapy intervention on autonomic function in anthracycline-treated breast cancer patients. Integrative Cancer Therapies, 10(4), 312-316. https://www.doi.org/10.1177/1534735411400311

Dimeo, F. C., Stieglitz, R. D., Novelli-Fischer, U., Fetscher, S., \& Keul, J. (1999). Effects of physical activity on the fatigue and psychologic status of cancer patients during chemotherapy. Cancer, 85(10), 2273-2277. https://www.doi.org/10.1002/(sici)10970142(19990515)85:10<2273::aid-cncr24>3.0.co;2-b

Encyclopaedia Britannica. (2019). Baroque music. https://www.britannica.com/art/Baroquemusic

National Cancer Institute. (2017). Types of cancer treatment. https://www.cancer.gov/aboutcancer/treatment/types

Tennant, K. F. (2019). Assessment of fatigue in older adults: The FACIT Fatigue Scale (version 4). https://consultgeri.org/try-this/general-assessment/issue-30.pdf.

WHO. (2018). Indonesia fact sheets. http://gco.iarc.fr/today/data/factsheets/populations/360indonesia-fact-sheets.pdf

WHO. (2018). Cancer today data. https://gco.iarc.fr/today/online-analysistable $? \mathrm{v}=2018 \&$ mode $=$ cancer $\&$ mode_population $=$ continents \&population $=900 \&$ populatio $\mathrm{ns}=360 \& \mathrm{key}=\mathrm{asr} \& \mathrm{sex}=2 \&$ cancer $=39 \&$ type $=0 \&$ statistic $=5 \&$ prevalence $=0 \&$ population_g roup $=0 \&$ ages_group $\% 5 \mathrm{~B} \% 5 \mathrm{D}=4 \&$ ages_group $\% 5 \mathrm{~B} \% 5 \mathrm{D}=7 \& \mathrm{nb}$ items $=5 \&$ group_cancer $=1 \&$ include_nmsc=1\&include_nmsc_other=1\#collapse-group-0-3

Wigram, T., Pedersen, I. N., \& Bonde, L. O. (2002). A comprehensive guide to music therapy: Theory, clinical practice, research and training. Athenaeum Press. 